\title{
INFLUENCE OF COMBINED HEAT TREATMENT AND DENSIFICATION ON MECHANICAL PROPERTIES OF POPLAR WOOD
}

\author{
Gonca Düzkale Sözbir ${ }^{l}$, Ibrahim Bektaş ${ }^{1, \star}$, Ayşenur Kiliç Ak ${ }^{l}$
}

\begin{abstract}
In this study, influence of combined heat treatment and densification on mechanical properties of poplar wood (Populus usbekistanica) such as density, EMC, compression strength, modulus of elasticy, modulus of rupture and static bending strength were investigated. Poplar samples were subjected to a temperature of $120^{\circ} \mathrm{C}, 160^{\circ} \mathrm{C}$ and $200^{\circ} \mathrm{C}$ for 1 and $3 \mathrm{~h}$. After the heat treatment, the heat treated samples were compressed in a hot press at a temperature of $120^{\circ} \mathrm{C}$, press pressure of $5 \mathrm{MPa}$ and press time of 30 minutes for densification. The results showed that the heat treatment affected the densification with increasing density. Additionally, the heat treatment decreased modulus of rupture (MOR), modulus of elasticity (MOE) and impact bending strength (IBS) with increasing temperature for undensified poplar wood. In conclusion, densification process has improved all the mechanical tested properties.
\end{abstract}

Keywords: Bending strenght, compression strength, density, EMC, Populus usbekistanica.

\section{INTRODUCTION}

Heat treatment is an effective method for improving the properties, dimensional stability and the durability of wood (Seborg et al. 1953, Kollmann and Scheiner 1963, Burmester 1973, Bourgois et al. 1998, Hill 2006, Gunduz et al. 2009). Besides being an eco-friendly process, modifications of wood decrease the hygroscopic irregularity (Navi and Sandberg 2012). Modifying the properties of wood using heat treatment is not a new method, it has been worked over centuries. Even in 1920, Tiemann reported that the high temperature drying decreased equilibrium moisture content and swelling of wood. Kollmann 1936, used high temperature and hotpress densification and called this process "Lignostone" and Seborg et al. (1945) generated a similar product called "Staypack" (Esteves and Pereira 2009).

Exposing heat treatment of wood makes it more fragile and rigid, so its mechanical strength decreases (Poncsak et al. 2006, Korkut et al. 2008, Korkut and Bektas 2008). Meanly, while the higher heat treatment temperature cause the lower the level of absorbed moisture and equilibrium moisture content (Tiemann 1920, Kollmann and Schneider 1963, Aydemir 2007), the wood becomes more brittle, and its mechanical strength and technological properties decrease in relation to the level of heat treatment (Gunduz et al. 2007). Most important parameters of heat treatment are temperature and holding time, but temperature has a greater effect on many wood properties than treatment time (Kartal et al. 2007). There have been some studies about this topic in literature. For example, according to Kol (2010) the heat-terated pine and fir's impact bending strength decreased by $63 \%$ and $9 \%$, respectively. Moreover, Korkut and Hiziroglu (2009) also evaluated the effect of heat treatment on impact bending strength and founded that increasing treatment temperature and duration decreased impact bending strength.

The densification of wood is defined as a procedure entailing compression process after heated wood. Densification makes it possible for low-density and commercially uninteresting wood species to be transformed 
into high performance and high value products (Kutnar et al. 2012). Since increasing the density of wood enhances its strength properties, there have been many studies on the densification of wood. In a study conducted by Kariz et al. (2017), spruce wood, thermally treated at $170^{\circ} \mathrm{C}, 190^{\circ} \mathrm{C}, 210^{\circ} \mathrm{C}$ and $230^{\circ} \mathrm{C}$ were surface densified by compression at a temperature of $150^{\circ} \mathrm{C}$ for 2 minutes. According to results, while mass loss increased with increasing temperature, equilibrium moisture content (EMC) decreased. Moreover, densification treatment increased value of modulus of rupture (MOR) and modulus of elasticity (MOE) but increasing heat temperature decreased these values. Ulker et al. (2012) noted that thermomechanical densification at $120^{\circ} \mathrm{C}$, $140^{\circ} \mathrm{C}$ and $160^{\circ} \mathrm{C}(6 \mathrm{MPa})$ increased density of scots pine wood by $93 \%$, but press temperature did not effect ratio of density. MOE and MOR of scots pine increased at $120^{\circ} \mathrm{C}$, but then these values decreased at increasing temperature. In another study, test samples were prepared from Scots pine (Pinus sylvestris L.) wood exposed to heat treatment at $130^{\circ} \mathrm{C}, 145^{\circ} \mathrm{C}, 160^{\circ} \mathrm{C}, 175^{\circ} \mathrm{C}, 190^{\circ} \mathrm{C}$ and $205^{\circ} \mathrm{C}$ for $3,6,9$ and 12 hours. MOR and MOE values of samples were also decreased with increasing treatment temperature and end of heat treatment at $205^{\circ} \mathrm{C}$ decreased by $50 \%$ (Yapici et al. 2013).

The focus of the present study was to indicate the effects of combined heat treatment and densification on the mechanical properties of poplar wood and evaluate the differences between these properties. The density, mass loss and equilubrium moisture content of surface densified wood without heat treatment were determined. Thus, the study included an assesment of the various mechanical properties of poplar wood, including compression strength, modulus of elasticity and modulus of rupture, impact bending strength.

\section{MATERIALS AND METHODS}

\section{Test specimens}

Test specimens were obtained from poplar wood (Populus usbekistanica) lumbers supplied in Kahramanmaraş territory from Turkey. Compression strength parallel to grain specimens $20 \times 20 \times 30 \mathrm{~mm}$, static bending strength and elastic modulus of bending specimens $20 \times 20 \times 360 \mathrm{~mm}$ as well as impact bending strength specimens $20 \times 20 \times 300 \mathrm{~mm}$ of sizes, were prepared for the laboratory experiment according to TS 2595 (1977), TS 2474 (1976) and TS 2477 (1976), respectively.

\section{Heat treatment application}

Specimens which had on average $10 \%$ moisture were heat treated at a temperature of $120^{\circ} \mathrm{C}, 160^{\circ} \mathrm{C}$ and $200^{\circ} \mathrm{C}$ during 60 and 180 minutes in the presence of air. During heat treatment application, $100 \mathrm{ml}$-water vapour was given to prevent cracks until the temperature reaches $100^{\circ} \mathrm{C}$ in oven. After reaching this temperature, vapour was removed and specimens were kept in oven until reaching target temperatures $\left(120^{\circ} \mathrm{C}, 160^{\circ} \mathrm{C}\right.$ and $\left.200^{\circ} \mathrm{C}\right)$. At the end of the heat treatment, the moisture of the samples became completely dry $(0 \%)$

\section{Densification process}

Before densification process, heat treated samples were conditioned in a test cabinet with a relative humidity of $65 \%$ and a temperature of $20^{\circ} \mathrm{C}$ for 3 weeks in order to avoid damage of the samples during the densification process. Thus, moistures were increased up to $5-7 \%$ by waiting for a while in the test cabinet. Thereafter, samples were pressed at $120^{\circ} \mathrm{C}$ under $5 \mathrm{MPa}$ pressure during 30 minutes in absence of vapour. After 30 minutes samples were cooled down in the press for 10 minutes without opening. To calculate $\mathrm{D}_{0}$, the pressurized samples were again dried in an oven at $103 \pm 2{ }^{\circ} \mathrm{C}$.

\section{The sample codes}

The sample codes generated according to the applied operations are shown in Table 1. 
Table 1: The sample codes and applied processes.

\begin{tabular}{|c|c|c|c|c|c|}
\hline \multirow{3}{*}{$\begin{array}{c}\text { Samples } \\
\text { Codes }\end{array}$} & \multicolumn{5}{|c|}{ Applied Processes } \\
\hline & \multicolumn{2}{|c|}{ Heat treatment } & \multicolumn{3}{|c|}{ Densification } \\
\hline & $\begin{array}{c}\text { Temperature } \\
\left({ }^{\circ} \mathrm{C}\right)\end{array}$ & $\begin{array}{c}\text { Duration } \\
\text { (h) }\end{array}$ & $\begin{array}{c}\text { Compression } \\
\text { (MPa) }\end{array}$ & $\begin{array}{c}\text { Temperature } \\
\left({ }^{\circ} \mathrm{C}\right)\end{array}$ & $\underset{\text { (h) }}{\text { Duration }}$ \\
\hline $\mathrm{CS}$ & - & - & - & - & - \\
\hline HT11 & 120 & 1 & - & - & - \\
\hline HT13 & 120 & 3 & - & - & - \\
\hline HT21 & 160 & 1 & - & - & - \\
\hline HT23 & 160 & 3 & - & - & - \\
\hline HT31 & 200 & 1 & - & - & - \\
\hline HT33 & 200 & 3 & - & - & - \\
\hline HTD11 & 120 & 1 & 5 & 120 & $1 / 2$ \\
\hline HTD13 & 120 & 3 & 5 & 120 & $1 / 2$ \\
\hline HTD21 & 160 & 1 & 5 & 120 & $1 / 2$ \\
\hline HTD23 & 160 & 3 & 5 & 120 & $1 / 2$ \\
\hline HTD31 & 200 & 1 & 5 & 120 & $1 / 2$ \\
\hline HTD33 & 200 & 3 & 5 & 120 & $1 / 2$ \\
\hline DS & - & - & 5 & 120 & $1 / 2$ \\
\hline
\end{tabular}

CS: Control sample, DS: Densified sample, HT: Heat treated, HTD: Heat treated densified.

\section{Mechanical properties}

The mechanical strength properties were determined according to the relevant standards are as follows Table 2.

Table 2: The mechanical strength properties.

\begin{tabular}{|c|c|}
\hline Tests & Standards \\
\hline Compression strength parallel to grain (CSP) & 1 \\
\hline Static bending strength (MOR) & 2 \\
\hline Modulus of elasticity in static bending (MOE) & 3 \\
\hline Impact bending strength (IBS) & 4 \\
\hline
\end{tabular}

${ }^{1}$ TS 2595. 1977. Wood-determination of ultimate stress in compression parallel to grain, TSE, Ankara.

${ }^{2}$ TS 2474. 1976. Wood-determination of ultimate strength in static bending, TSE, Ankara.

${ }^{3}$ TS 2478. 1976. Wood-determination of modulus of elasticity in static bending, TSE, Ankara

${ }^{4}$ TS 2477. 1976. Wood-determination of impact bending strength; Turkish Standart Institute, Ankara Turkey.

\section{Other calculations}

The values of the compression ratio, oven dry density, equilibrium moisture content and mass loss were determined by the assumption that they would contribute to the evaluation of the data of the mechanical properties calculated under different conditions. The compression ratio $(\mathrm{CR})$, oven dry density $\left(\mathrm{D}_{0}\right)$, mass loss (ML) and equilibrium moisture content (EMC) were calculated by Equation 1, Equation 2, Equation 3 and 
Equation 4 givens below:

$$
\begin{gathered}
\mathrm{CR}(\%)=\frac{\text { Compressed thickness }(\mathrm{mm})}{\text { Initial thickness }(\mathrm{mm})} \times 100 \\
\mathrm{D}_{0}\left(\mathrm{~kg} / \mathrm{m}^{3}\right)=\frac{\text { Oven dry weight }(\mathrm{kg})}{\text { Oven dry volume }\left(\mathrm{m}^{3}\right)}
\end{gathered}
$$

$$
\begin{aligned}
& \operatorname{ML}(\%)=\frac{\text { First weight }(\mathrm{g})-\text { Last weight }(\mathrm{g})}{\text { First weight }(\mathrm{g})} \times 100 \\
& \operatorname{EMC}(\%)=\frac{\text { Wet weight }(\mathrm{g})-\text { Oven dry weight }(\mathrm{g})}{\text { Wet weight }(\mathrm{g})} \times 100
\end{aligned}
$$

Where; wet weight of samples were calculated after they reached constant weight at $65 \% \mathrm{rH}$ and $20^{\circ} \mathrm{C}$ in the test cabinet.

\section{Statistical analyzes}

The results were analysed using one-way ANOVA from the SPSS statistical software program and Duncan's mean separation test to populate homogeneity groups that showed significant differences at the $95 \%$ confidence level.

\section{RESULTS AND DİSCUSSİON}

The results of the ANOVA and Duncan's mean separation tests for the oven-dry density $\left(\mathrm{D}_{0}\right)$, mass loss percentage (ML), equilibrium moisture content (EMC) and compression strenght parallel to grain (CSP) values

\begin{tabular}{|c|c|c|c|c|c|}
\hline $\begin{array}{l}\text { Sample } \\
\text { codes }\end{array}$ & $\begin{array}{l}\text { CR } \\
(\%)\end{array}$ & $\mathrm{D}_{0}\left(\mathrm{~kg} / \mathrm{m}^{3}\right)$ & ML (\%) & EMC (\%) & CSP (MPa) \\
\hline CS & - & $330(20)^{(*)} \mathrm{a}^{(* *)}$ & - & $9,81(0,24) \mathrm{g}$ & $35,6(2,54) a$ \\
\hline \multicolumn{6}{|l|}{ HT } \\
\hline HT11 & - & $332(20) a$ & $0,26(0,23) \mathrm{ab}$ & $10,88(0,19) \mathrm{h}$ & $34,6(3,02) a$ \\
\hline HT13 & - & $326(20) \mathrm{a}$ & $0,71(4,61) \mathrm{abc}$ & $9,87(0,23) \mathrm{g}$ & $35,2(2,13) \mathrm{a}$ \\
\hline HT21 & - & $333(20) \mathrm{a}$ & $0,34(0,20) \mathrm{ab}$ & $9,74(0,20) \mathrm{g}$ & $36,2(2,40) a$ \\
\hline HT23 & - & $328(20) \mathrm{a}$ & $1,24(0,34) b c$ & $9,76(0,29) \mathrm{g}$ & $\begin{array}{c}36,9(2,29) \\
\mathrm{ab}\end{array}$ \\
\hline HT31 & - & $327(20) \mathrm{a}$ & $3,48(1,56) \mathrm{d}$ & $7,98(0,32) \mathrm{c}$ & $39,7(2,88) b$ \\
\hline HT33 & - & $319(20) \mathrm{a}$ & $5,19(2,10) \mathrm{e}$ & $7,30(0,28) \mathrm{b}$ & $39,8(2,53) \mathrm{b}$ \\
\hline \multicolumn{6}{|l|}{ HTD } \\
\hline HTD11 & 35 & $928(50) \mathrm{de}$ & $0,53(0,27) \mathrm{abc}$ & $8,56(0,19) \mathrm{e}$ & $67,3(6,98) \mathrm{f}$ \\
\hline HTD13 & 37 & $850(40) \mathrm{c}$ & $0,68(0,56) \mathrm{abc}$ & $8,77(0,26)$ ef & $59,0(5,75) \mathrm{d}$ \\
\hline HTD21 & 34 & $947(5) \mathrm{e}$ & $0,47(0,29) \mathrm{abc}$ & $8,09(0,19) \mathrm{cd}$ & $64,0(7,65) \mathrm{e}$ \\
\hline HTD23 & 35 & $951(40) \mathrm{e}$ & $1,56(0,42) \mathrm{c}$ & $8,22(0,37) \mathrm{d}$ & $63,5(8,24) \mathrm{e}$ \\
\hline HTD31 & 34 & $807(110) \mathrm{b}$ & $3,43(0,97) \mathrm{d}$ & $6,79(0,17) a$ & $55,3(9,42) \mathrm{d}$ \\
\hline HTD33 & 39 & $817(60) b$ & $5,74(0,81) \mathrm{d}$ & $7,51(0,27) \mathrm{b}$ & $51,1(8,36) \mathrm{c}$ \\
\hline DS & 36 & $919(80) \mathrm{d}$ & - & $8,90(0,28) \mathrm{f}$ & $76,3(9,10) \mathrm{g}$ \\
\hline \multicolumn{2}{|c|}{ Probability } & $\mathrm{p}<0,001$ & $\mathrm{p}<0,001$ & $\mathrm{p}<0,001$ & $\mathrm{p}<0,001$ \\
\hline
\end{tabular}
measured in the test and statistical analysis are shown in Table 3.

Table 3: Average values of $\mathrm{D}_{0}, \mathrm{ML}, \mathrm{EMC}$ and CS in poplar wood specimens before (undensified) and after densification process.

${ }^{(*)}$ The values in parentheses indicate standard deviation, ${ }^{\left({ }^{* *}\right.}$ Mean values followed by the same lowercase letter are not significantly different (according to Duncan's mean separation test). 
Data obtained from Table 3 showed that, heat treatment effect on compression strength, equilibrium moisture content and mass loss values, forming a significant difference $(p<0,001)$ between heat treated (HT) and heat treated densified (HTD) poplar wood specimens. Concurrently, heat treatment effect on HT specimens was quite low $(0,6 \%)$ when compared to control samples densities. Whereas, the highest decrease percentage in densities was measured in HT33, the maximum increase was obtained in HT21. In the light of these evaluations it can be said that heat treatment applied to the specimens prior to densification process has not got a significant impact on density. While heat treatment decreased the average density of densified specimens in the ratio of $4 \%$, average density values of densified samples (DS) and HTD samples increased in the order of $178 \%$ and $167 \%$. The highest density value was reached in HTD21 and HTD23. According to these data, heat treatment temperature had an impact on wood density in densified poplar wood. Densified poplar wood density calculated at a temperature of $200^{\circ} \mathrm{C}$ (HTD31, HTD33) was decreased in comparison with obtained values in other heat treatment temperatures.

Whereas, densification process did not cause mass loss, heat treatment caused mass loss depending on increasing temperature and heat duration. At temperature of $200^{\circ} \mathrm{C}, 160^{\circ} \mathrm{C}$ and $120^{\circ} \mathrm{C}$, average mass loss values in undensified specimens were calculated as of $4,3 \% ; 0,8 \%$ and $0,5 \%$ and related values in densified specimens as $4,6 \% ; 1 \%, 0,6 \%$; respectively. These values indicated that mass loss resultant $200^{\circ} \mathrm{C}$ was higher than those of $120^{\circ} \mathrm{C}$ and $160^{\circ} \mathrm{C}$.

Compared to control samples, while avarage EMC values in samples subjected to $120^{\circ} \mathrm{C}$ increased $6 \%$, $160^{\circ} \mathrm{C}$ and $200^{\circ} \mathrm{C}$ decreased $1 \%$ and $22 \%$, respectively. In here, the highest decrease in EMC values were obtained in HTD31 and HTD33 (Table 3). Similarly, wood veneer specimens made with aspen (Populus tremuloides) and hybrid poplar clone were densified using heat, steam, and pressure at $140^{\circ} \mathrm{C}, 160^{\circ} \mathrm{C}, 180^{\circ} \mathrm{C}$, $200^{\circ} \mathrm{C}$ and $220^{\circ} \mathrm{C}$ temperature (steam pressure of $550 \mathrm{kPa}$ ) by Fang et al. (2012) and they found that increasing temperature decreased value of EMC.

In previous studies CSP values were decreased with the increasing temperature (Sulzberger 1955, Manriquez and Moraes 2010, Zhong et al. 2016). For, in this study CSP values has increased in HT samples (Figure 1a). This can be explained by the decrease in the holocellulose ratio (7\%), which is the result of mass loss due to the increase in temperature (Bektas et al. 2017). At the same time, as can be seen from Table 3, the effect of temperature on the CSP is statistically different between 120 and $200^{\circ} \mathrm{C}$ samples according to Duncan test. Here, the reduction of EMC values was also effective. Comparing the CSP values of HTD samples with the CS, a remarkable increase $(68,6 \%)$ was observed after densification process. Meanwhile, CSP values of HTD samples increased averagely $61,96 \%$ than HT samples. At the same time, CSP values of DS samples increased by $114 \%$ compared to CS. Also, Ulker et al. (2012) densified scots pine specimens by thermomechanical densification process using $120^{\circ} \mathrm{C}, 140^{\circ} \mathrm{C}$ and $160^{\circ} \mathrm{C}$ under 6 Mpa pressure. They determined that compression strength values increased with the densification process in densified scots pine specimens; however, it decreased with the increase of press temperature. In yet another study, pine and fir wood exposed to thermowood process at a temperature of $212^{\circ} \mathrm{C}$ and $190^{\circ} \mathrm{C}$ for 2 hours, $\mathrm{Kol}(2010)$ stated that compression strength values increased $4 \%$ and $17 \%$, respectively.

Table 4 shows the MOE and MOR values of densified and undensified poplar wood specimens with and without heat treatment calculated based on $\mathrm{D}_{0}$, ML, EMC values. 
Table 4: The mean values of MOE and MOR tests.

\begin{tabular}{|c|c|c|c|c|c|c|}
\hline $\begin{array}{l}\text { Sample } \\
\text { codes }\end{array}$ & $\begin{array}{l}\text { CR } \\
(\%)\end{array}$ & $\begin{array}{c}D_{0} \\
\left(\mathrm{~kg} / \mathrm{m}^{3}\right)\end{array}$ & $\begin{array}{l}\text { ML } \\
(\%)\end{array}$ & $\begin{array}{c}\text { EMC } \\
(\%)\end{array}$ & $\begin{array}{l}\text { MOE } \\
(\mathrm{MPa})\end{array}$ & $\begin{array}{l}\text { MOR } \\
(\mathrm{MPa})\end{array}$ \\
\hline CS & - & $325(20)^{(*)} \mathrm{ab}^{(* *)}$ & - & $9,01(0,94) \mathrm{f}$ & $5693(286) \mathrm{a}$ & $59,02(2,99) \mathrm{c}$ \\
\hline \multicolumn{7}{|l|}{ HT } \\
\hline HT11 & - & $337(20) b$ & $0,41(0,45) \mathrm{a}$ & $7,53(0,26) \mathrm{c}$ & $5960(580) \mathrm{a}$ & $59,9(4,94) \mathrm{c}$ \\
\hline HT13 & - & $340(30) \mathrm{b}$ & $1,22(0,18) a b$ & $7,55(0,27) \mathrm{c}$ & $5918(432) \mathrm{a}$ & $59,8(3,31) \mathrm{c}$ \\
\hline HT21 & - & $334(20) \mathrm{b}$ & $2,27(0,22) \mathrm{cd}$ & $7,63(0,23) \mathrm{c}$ & $5727(476) \mathrm{a}$ & $58,1(4,18) \mathrm{c}$ \\
\hline HT23 & - & $333(20) b$ & $2,65(0,17) \mathrm{de}$ & $8,13(0,23) \mathrm{d}$ & $5931(368) \mathrm{a}$ & $58,3(2,36) \mathrm{c}$ \\
\hline HT31 & - & $297(20) \mathrm{a}$ & $9,40(1,77) \mathrm{h}$ & $5,42(0,16) \mathrm{a}$ & $5178(441) \mathrm{a}$ & $41,2(6,72) b$ \\
\hline HT33 & - & 311(30)ab & $10,76(2,40)_{1}$ & $5,49(0,22) \mathrm{a}$ & $5107(540) \mathrm{a}$ & $33,4(10,95) \mathrm{a}$ \\
\hline \multicolumn{7}{|l|}{ HTD } \\
\hline HTD11 & 35 & $778(50) \mathrm{e}$ & $1,40(0,13) b c$ & $8,50(0,28) \mathrm{e}$ & $12117(1057) \mathrm{e}$ & $89,1(12,13) \mathrm{ef}$ \\
\hline HTD13 & 37 & $791(60) \mathrm{ef}$ & $1,20(0,13) \mathrm{ab}$ & $8,46(0,26) \mathrm{e}$ & 11931(1271)de & $91,7(8,51) \mathrm{f}$ \\
\hline HTD21 & 34 & $819(70) \mathrm{f}$ & $2,42(0,21) \mathrm{d}$ & $7,98(0,21) \mathrm{d}$ & $12015(733) \mathrm{e}$ & $91,1(7,96) \mathrm{f}$ \\
\hline HTD23 & 35 & $676(80) \mathrm{cd}$ & $3,30(1,96)$ ef & $7,72(0,18) \mathrm{c}$ & $11110(916) \mathrm{c}$ & $82,8(8,19) \mathrm{e}$ \\
\hline HTD31 & 34 & $696(80) \mathrm{d}$ & $4,21(0,81) \mathrm{f}$ & $7,02(0,26) \mathrm{b}$ & 11174(901)cd & $74,8(12,33) \mathrm{d}$ \\
\hline HTD33 & 39 & $656(90) \mathrm{c}$ & $5,71(1,08) \mathrm{g}$ & $6,91(0,89) \mathrm{b}$ & $9768(2,017) \mathrm{b}$ & $57,5(15,26) \mathrm{c}$ \\
\hline DS & 36 & $708(80) d$ & - & $8,42(0,27) \mathrm{e}$ & 13105 (1168)f & $101,3(13,71) \mathrm{g}$ \\
\hline \multicolumn{2}{|c|}{ Probability } & $\mathrm{p}<0,001$ & $\mathrm{p}<0,001$ & $\mathrm{p}<0,001$ & $\mathrm{p}<0,001$ & $\mathrm{p}<0,001$ \\
\hline
\end{tabular}

${ }^{(*)}$ The values in parentheses indicate standard deviation, ${ }^{\left({ }^{* *}\right.}$ Mean values followed by the same lowercase letter are not significantly different (according to Duncan's mean separation test).

Data in Table 4 revealed that HT and HTD poplar wood samples densities increased until $200^{\circ} \mathrm{C}$. As for the decreasing in $200^{\circ} \mathrm{C}$, it can be explained by degradation of the chemical components occuring when the poplar woods were exposed to above $160^{\circ} \mathrm{C}$ (Bektas et al. 2017). Likewise, Boonstra et al. (2007a) reported a decrease in density of heat-treated Scots pine and Norway spruce $\left(<200^{\circ} \mathrm{C}\right)$ by $10 \%$ and $8,5 \%$, respectively. Compared control samples of both process, it can be seen that densification process increased oven-dry density about $118 \%$. The most notable decrease in density of HTD samples was measured at HTD23 and above temperatures compared to DS $\left(708 \mathrm{~kg} / \mathrm{m}^{3}\right)$.

Table 4 shows that average mass loss values at $200^{\circ} \mathrm{C}, 160^{\circ} \mathrm{C}$ and $120^{\circ} \mathrm{C}$ tempereatures in $\mathrm{HT}$ samples calculated as of $10,1 \% ; 2,5 \%$ and $0,8 \%$ and related values in HTD samples as $5 \% ; 2,9 \% ; 1,3 \%$, respectively. The EMC value of the control group was $9,01 \%$. Also, the EMC values of poplar samples decreased after HT and HTD processes. This decrease occurred proportionate with directly mass loss. Accordingly, it can be deduced that increases in mass loss can decrease EMC value.

MOE values of DS were found to be $130 \%$ increased in comparison with CS. While MOE values of HT samples subjected to $120^{\circ} \mathrm{C}$ and $160^{\circ} \mathrm{C}$ increased, this value decreased in samples exposed to $200^{\circ} \mathrm{C}$ (Figure 1c). Besides, MOE of HTD samples decreased with increasing heat treatment temperature and duration as seen in Figure 1c. Comparing the MOR values of DS with CS, after densification process, an increase of MOR values by $72 \%$ was detected. The MOR values of heat treated poplar wood samples increased at $120^{\circ} \mathrm{C}$, but decreased at high temperatures (Figure 1b). In other words, densification process increased MOR values, however; it was understood from Table 4 that increasing the applied heat treatment temperature and duration caused decrease of MOR values. A great number of researchers stated that MOE and MOR values of wood showed slight increase in low temperature and short-term heat treatment application (Bekhta and Niemz 2003, Poncsak et al. 2006, Shi et al. 2007). However; it has been emphasized that heat treatment applications with high temperature degrees decreased these values at varying rates. For instance, Kamdem et al. (2002), MOR and MOE of beech 40\%, Bekhta and Niemz (2003) MOR of spruce 44-50\%, Korkut et al. (2008), MOE and MOR of scots pine 27-33\% ratios determined decrease. In another study, Cao et al. (2012) treated to Chinese fir at a temperature ranging from $170^{\circ} \mathrm{C}$ to $230^{\circ} \mathrm{C}$ and time from 1 to 5 hours and found that both MOE and MOR values increased under less than $200^{\circ} \mathrm{C}$, but decreased above this temperature. Similarly, Poncsak et al. (2006) noted that heat-treated birch showed a reduction of MOR with increasing treatment temperature. It is well known that MOE properties of wood are correlated with density. It has also been confirmed by Percin et al. (2016) that the modulus of elasticity increases as the density increases. 
Table 5: The analyses results of Impact bending strength test.

\begin{tabular}{|l|l|l|l|l|l|}
\hline Sample codes & $\begin{array}{c}\text { CR } \\
(\%)\end{array}$ & \multicolumn{1}{|c|}{$\mathrm{D}_{0}\left(\mathrm{~kg} / \mathrm{m}^{3}\right)$} & \multicolumn{1}{|c|}{ ML $(\%)$} & \multicolumn{1}{|c|}{ EMC $(\%)$} & \multicolumn{1}{|c|}{ IBS $\left(\mathrm{kJ} / \mathrm{m}^{2}\right)$} \\
\hline CS & - & $339(40)^{(*)} \mathrm{a}$ & - & $7,91(0,32) \mathrm{gh}$ & $034(0,05) \mathrm{cd}$ \\
\hline HT & & & & & \\
\hline HT11 & - & $340(40) \mathrm{a}$ & $0,58(0,23) \mathrm{a}$ & $8,04(0,42) \mathrm{h} 1$ & $35(0,08) \mathrm{cd}$ \\
\hline HT13 & - & $343(20) \mathrm{a}$ & $1,06(0,19) \mathrm{a}$ & $8,08(0,30) \mathrm{h} 1$ & $41(0,09) \mathrm{def}$ \\
\hline HT21 & - & $328(10) \mathrm{a}$ & $2,26(0,24) \mathrm{bc}$ & $8,48(0,34) \mathrm{h} 1$ & $31(0,07) \mathrm{c}$ \\
\hline HT23 & - & $331(20) \mathrm{a}$ & $3,03(0,30) \mathrm{c}$ & $7,53(0,36) \mathrm{f}$ & $27(0,06) \mathrm{bc}$ \\
\hline HT31 & - & $311(10) \mathrm{a}$ & $5,51(1,32) \mathrm{e}$ & $5,73(0,33) \mathrm{b}$ & $22(0,03) \mathrm{ab}$ \\
\hline HT33 & - & $318(40) \mathrm{a}$ & $10,15(2,23) \mathrm{g}$ & $5,29(0,21) \mathrm{a}$ & $16(0,03) \mathrm{a}$ \\
\hline HTD & & & & & \\
\hline HTD11 & 35 & $797(60) \mathrm{d}$ & $0,72(0,20) \mathrm{a}$ & $8,16(0,30) 1$ & $48(0,11) \mathrm{fg}$ \\
\hline HTD13 & 37 & $795(60) \mathrm{d}$ & $1,16(0,18) \mathrm{a}$ & $8,05(0,23) \mathrm{h} 1$ & $47(0,11) \mathrm{fg}$ \\
\hline HTD21 & 34 & $797(60) \mathrm{d}$ & $2,15(0,16) \mathrm{b}$ & $7,78(0,27) \mathrm{g}$ & $45(0,10) \mathrm{efg}$ \\
\hline HTD23 & 35 & $692(80) \mathrm{b}$ & $3,00(0,41) \mathrm{c}$ & $7,21(0,60) \mathrm{e}$ & $43(0,15) \mathrm{efg}$ \\
\hline HTD31 & 34 & $757(70) \mathrm{c}$ & $4,39(0,39) \mathrm{d}$ & $6,86(0,36) \mathrm{d}$ & $39(0,09) \mathrm{de}$ \\
\hline HTD33 & 39 & $661(80) \mathrm{b}$ & $7,30(1,40) \mathrm{f}$ & $6,38(0,23) \mathrm{c}$ & $28(0,10) \mathrm{bc}$ \\
\hline DS & 36 & $755(90) \mathrm{c}$ & - & $7,90(0,29) \mathrm{gh}$ & $50(0,06) \mathrm{g}$ \\
\hline Probability & & $\mathrm{p}<0,001$ & $\mathrm{p}<0,001$ & $\mathrm{p}<0,001$ & $\mathrm{p}<0,001$ \\
\hline
\end{tabular}

${ }^{(*)}$ The values in parentheses indicate standard deviation, ${ }^{(* *)}$ Mean values followed by the same lowercase letter are not significantly different (according to Duncan's mean separation test).

Table 5 showed that effect of heat treatment on $\mathrm{D}_{0}\left(\mathrm{~kg} / \mathrm{m}^{3}\right)$, ML $(\%)$, EMC $(\%)$ and IBS $\left(\mathrm{kJ} / \mathrm{m}^{2}\right)$ differed between HT and HTD samples. An increase in density value was observed when heat treatment duration raises from 1 to 3 hours at a temperature of $120^{\circ} \mathrm{C}$ for HT poplar wood. This is because, heat treatment with steam increased thermal conductivity of wood and the thermal conductivity increased density. Densification process has increased density of samples. Accordingly, density of DS demonstrated an increase about $123 \%$.

The mass loss values had significant differences in $160^{\circ} \mathrm{C}$ and $200^{\circ} \mathrm{C}$ for HT and HTD samples, but at $120^{\circ} \mathrm{C}$ there is no statistical difference for both processes. As the process temperature and duration have increased, mass loss also increased for HT and HTD samples. According to Bourgois and Guyonnet (1988), the mass losses are quite high at higher temperatures. As seen in Table 5, there was no significant difference between the EMC values of the control groups and the samples treated at $120^{\circ} \mathrm{C}$, whereas significant differences have been observed between the HT and HTD samples depending on the duration at all other temperatures. Jamsa and Viitaniemi (2001) noted that the reason for the decrease of the EMC is that cell walls absorbe less water after the heat treatment as a result of chemical changes in wood cells. Moreover, the decrease of the EMC owing to heat treatment leads to an improvement of dimensional stability (Esteves and Pereira 2009).

The IBS values of the control samples increased by an average of $47 \%$ after densification process. IBS values increased at $120^{\circ} \mathrm{C}$ depending on the duration and density after heat treatment process. Additionally, IBS values decreased at temperature of $160^{\circ} \mathrm{C}$ and above inverse proportion with the mass loss. On the other hand, the densification process increased the IBS value compared with HT samples (Figure 1d). However, as the temperature and application duration have increased, IBS values decreased for HTD samples. In a study conducted by Bal and Efe (2016) on the subject, it is stated that the applied heat treatment temperatures of $180^{\circ} \mathrm{C}, 200^{\circ} \mathrm{C}$ and $220^{\circ} \mathrm{C}$ cause the IBS strength of Fagus orientalis wood to decrease by $31 \% ; 62 \%$ and $72 \%$, respectively. Also, Dundar et al. (2012) found that the increase in temperature reduces the IBS value of the black pine specimens as a result of the steam heat treatment applied at $180^{\circ} \mathrm{C}$ and $200^{\circ} \mathrm{C}$ for 3 hours. In a research performed with Scots pine, radiata pine and Norway spruce specimens, after heat treatment the impact strength showed a decrease (Boonstra et al. 2007a).

Table 6 shows the change percentages of mechanical properties of undensified and densified wood with and without heat treatment according to the control specimens. 
Table 6: Changes of mechanical properties according to the application of heat treatment and densification processes.

\begin{tabular}{|l|c|c|c|c|}
\hline Treatments & CSP (\%) & MOE (\%) & MOR (\%) & IBS (\%) \\
\hline CS & - & - & - & - \\
\hline HT11 & $-2,81$ & 4,69 & 1,44 & 2,94 \\
\hline HT13 & $-1,12$ & 3,95 & 1,37 & 5,88 \\
\hline HT21 & 1,69 & 0,60 & $-1,29$ & $-8,82$ \\
\hline HT23 & 3,65 & 0,14 & $-1,59$ & $-20,59$ \\
\hline HT31 & 11,52 & $-9,05$ & $-30,16$ & $-35,29$ \\
\hline HT33 & 11,80 & $-10,29$ & $-43,34$ & $-52,94$ \\
\hline HTD11 & 89,04 & 112,84 & 50,97 & 41,18 \\
\hline HTD13 & 65,73 & 109,57 & 55,29 & 38,24 \\
\hline HTD21 & 79,78 & 111,05 & 54,42 & 32,35 \\
\hline HTD23 & 78,37 & 95,15 & 40,24 & 26,47 \\
\hline HTD31 & 55,34 & 96,28 & 26,72 & 14,71 \\
\hline HTD33 & 43,54 & 71,58 & $-2,58$ & $-17,65$ \\
\hline DS & 114,33 & 130,19 & 71,59 & 47,06 \\
\hline
\end{tabular}

When Table 6 is examined in general, changes of CSP values in HT samples increased with increasing temperature, but in HTD samples these changes decreased. In contrast to temperature, changes of CSP values in HTD samples have inversely proportional with increasing duration. The maximum changes in CSP values were obtained in HT33 (12\%) and HTD11 (89\%) in both processes. In the literature, Boonstra et al. (2007a) found $28 \%$ and $8 \%$ increase on compressive strength parallel to the fibres and in tangential for heat-treated Scots pine, respectively.

As for the MOE and MOR changes in HT samples, values decreased at varying rates with increasing temperature and duration except for HT23. MOE changes ratio decreased from 112,84 to 96,28 for $1 \mathrm{~h}$ temperature application in HTD samples. For $3 \mathrm{~h}$ application values decreased from 109,57 to 71,58. Namely, the highest MOE values were reached in $1 \mathrm{~h}$ application than $3 \mathrm{~h}$. In the MOR values, all values except HTD33 increased by varying rates $(26,72-55,29 \%)$ in HTD samples compared to the control sample. In contrast to these results, Boonstra et al. (2007b) obtained a 6\% reduction in bending strength, but a 17\% increase on MOE in treated Norway spruce wood.

As it is also clear in Table 6 that IBS strength values decreased with the increase of temperature and duration in both processes except HT13. The maximum percentage decrease in general was measured in HT33 IBS value. Furthermore, IBS values increased at all temperatures in HTD samples except HTD33 compared to the control samples, while in HT samples IBS values decreased except HT13. This is because of the higher density in HT13 samples $\left(343 \mathrm{~kg} / \mathrm{m}^{3}\right)$.

Moreover, densification application increased the strength values of CSP, MOE, MOR and IBS by 114,33\%; $130,19 \% ; 71,59 \%$ and $47,06 \%$, respectively. That is, as seen in Figure 1, densification process increased all the mechanical properties, however; only heat treatment application decreased strength values except compression strength at $200^{\circ} \mathrm{C}$. In addition to these assessments, it can be said that the unexpected deviations seen in Table 5 were caused by the changes in density and mass loss of the samples. Moreover, Jiang et al. (2009) stated that $160^{\circ} \mathrm{C}$ treatment temperature is probably enough to cause degradation lignin molecules, to change their position and harm the adhesive linkage of lignin with cellulose fibrils. 

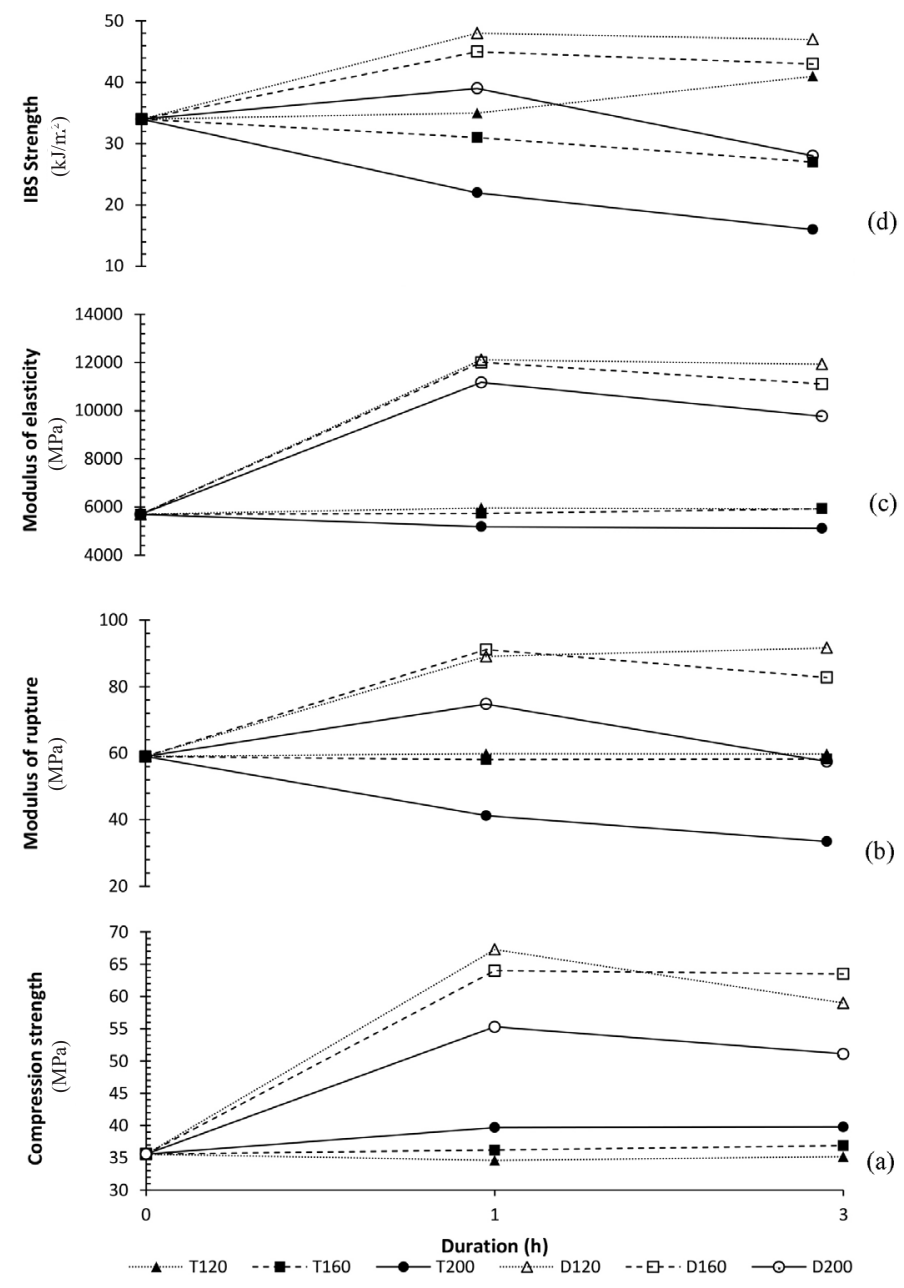

Figure 1: The strength-duration curves of mechanical strength values (a) compression strength, (b) modulus of rupture, (c) modulus of elasticity, (d) IBS) and durations.

When Figure 1 is examined, except for CSP, the other mechanical properties showed a decrease after the heat treatment. When the heat treatment times are taken into consideration, it is seen that the reduction in the mechanical properties of the samples subjected to the heat treatment for 3 hours is much more than that for the heat treatment for 1 hour.

By evaluating the same graph according to the heat treatment temperature, it is observed that as the temperature increases, the mechanical properties reduce parallel to the duration-related results, but this does not occur in the case of CSP samples subjected to only heat treatment. Instead, the CSP values increases as the temperature increases.

\section{CONCLUSIONS}

The main results obtained from this study can be summarized as follows. The density was influenced by heat treatment before densification and no homogeneous relationship has been determined between density and duration. The value of EMC generally decreased with increasing heat treatment temperature and densification 
at all mechanical tests specimens. In mechanical properties, the modulus of rupture, modulus of elasticity and impact bending strength were affected negatively by increasing heat treatment temperature. But, densification process generally increased the mechanical properties of poplar wood. Taking the effect of temperature and duration on mechanical properties into account, it was determined that in $200^{\circ} \mathrm{C}$ the effect of the duration on the mechanical properties was more notable in heat treated samples, while at the other temperatures the effect of them was close to each other.

\section{REFERENCES}

Aydemir, D. 2007. The effect of heat treatment on some physical, mechanic and technological properties of Uludag Fir (Abies bornmülleriana Mattf.) and Hornnbeam (Carpinus betulus L.) wood. Master Thesis, Zonguldak Karaelmas University, Zonguldak, Turkey. Available from: $<$ https://tez.yok.gov.tr/UlusalTezMerkezi/ tezSorguSonucYeni.jsp $>$ (consulted: 29.07.2019).

Bal, B.C.; Efe, F.T. 2016. Isıl işlemin kayın (Fagus orientalis L.) odununun şok direnci üzerine etkilerinin incelenmesi. 1st International Conference on Engineering Technology and Applied Sciences Afyon Kocatepe University, 21-22 April 2016.

Bekhta, P.; Niemz, P. 2003. Effect of high temperature on the change in color, dimensional stability and mechanical properties of spruce wood. Holzforschung 57(5): 539-546.

Bektas, I.; Duzkale Sozbir, G.; Bal, B.C.; Altuntas, E. 2017. Effects of the thermal and thermally compressed modification treatments on chemical properties of the poplar woods. KSU Journal of Engineering Sciences 20(1): 31-37.

Boonstra, M.; Van Acker, J.; Tjeerdsma, B.; Kegel, E. 2007a. Strength properties of thermally modified softwoods and its relation to polymeric structural wood constituents. Ann Forest Sci 64(7):679-690.

Boonstra, M.; Van Acker, J.; Kegel, E. 2007b. The effects of a two-stage heat treatment process on the mechanical properties of full construction timber. Wood Mater Sci Eng 2(3-4):138-146.

Bourgois, J.; Guyonnet, R. 1988. Characterisation and analysis of torrefied wood. Wood Science and Technology 22(2):143-155.

Bourgois, J.; Bartholin, M.C.; Guyennet, R. 1998. Thermal treatment of wood: Analysis of the obtained product. Wood Science and Technology 23(4): 303-310.

Burmeste, R.A. 1973. Investigations on the dimensional stabilization of wood. Bundesanstalt für Materialprüfung, Berlin-Dahlem, 50-56.

Cao, Y.; Lu, J.; Huang, R.; Zhao, X.; Jiang, J. 2012. Effect of steam-heat treatment on mechanical properties of chinese fir. BioResources 7(1): 1123-1133.

Dundar, T.; Buyuksari, U.; Avci, E.; Akkilic, H. 2012. Effect of heat treament on the physical and mechanical properties of compression and opposite wood of Black Pine. BioResources 7(4): 5009-5018.

Esteves, B.; Pereira, H. 2009. Wood modification by heat treatment: A review. BioResources 4(1): 370404.

Fang, C.H.; Marıtti, N.; Cloutier, A.; Koubaa, A.; Blanchet, P. 2012. Densification of wood veneers by compression combined with heat and steam. European Journal of Wood and Wood Products 70(1-3): 155163.

Gunduz, G.; Korkut, S.; Korkut, D.S. 2007. The effects of heat treatment on physical and technological properties and surface roughness of Camiyani Black Pine (Pinus nigra Arn. subsp. pallasiana var. pallasiana) 
wood. Bioresource Technology 99(7):2275-2280.

Gunduz, G.; Korkut, S.; Aydemir, D.; Bekar, I. 2009. The density, compression strength and surface hardness of heat treated hornbeam (Carpinus betulus L.) wood. Maderas-Cienc Tecnol 11(1): 61-70.

Hill, C. 2006. Wood modification-chemical, thermal and other processes. Wiley Series in Renewable Resources, John Wiley \& Sons, Ltd.

Jamsa, S.; Viitaniemi, P. 2001. Heat treatment of wood- Better durability without chemicals. Proceedings of special seminar Environmental Optimisation of Wood Protection held in Antibes, France.

Jiang, J.; Lu, J.; Huang, R.; Li, X. 2009. Effects of time and temperature on the viscoelastic properties of Chinese fir wood. Drying Technology 27(11): 1229-1234.

Kamdem, D.P.; Pizzi, A.; Jermannaud, A. 2002. Durability of heat-treated wood. European Journal of Wood and Wood Products 60(1): 1-6.

Kariz, M.; Kuzman, M.K.; Sernek, M.; Hughes, M.; Rautkari, L.; Kamke, F.A.; Kutnar, A. 2017. Influence of temperature of thermal treatment on surface densification of spruce. European Journal of Wood and Wood Products 75(1): 113-123.

Kartal, S.N.; Hwang, W.J.; Imamura, Y. 2007. Water absorption of boron-treated and heat-modified wood. Journal of Wood Science 53(5): 454-457.

Kol, H.S. 2010. Characteristics of heat-treated Turkish pine and fir wood after ThermoWood processing. Journal of Environmental Biology 31(6): 1007-1011.

Kollmann, F. 1936. Technologie des Holzes und der Holzwerkstoffe. Springer Verlag, Berlin.

Kollmann, F.; Schneider, A. 1963. On the sorption behaviour of heat stabilized wood. Holz Roh-Werkst 21(3):77-85.

Korkut, S.; Akgul, M.; Dundar, T. 2008. The effect of heat treatment on some technological properties of scots pine (Pinus sylvestris L.) wood. Bioresource Technology 99(6): 1861-1868.

Korkut, S.; Bektas, I. 2008. The effects of heat treatment on physical properties of Uludag fir (Abies bornmuelleriana Mattf.) and Scots pine (Pinus sylvestris L.) wood. Forest Products Journal 58(3): 95-99.

Korkut, S.; Hiziroglu, S. 2009. Effect of heat treatment on mechanical properties of hazelnut wood (Corylus colurna L.). Materials \& Design 30(5): 1853-1858.

Kutnar, A.; Wıdmann, R.; Kamke, F.A. 2012. Density, mechanical properties, and morphology of densified wood in relation to compression temperature and steam environments. Proceedings of the Sixth European Conference on Wood Modification, Ljubljana, Slovenia, 167-174.

Manriquez, M.J.; Moraes, P.D. 2010. Influence of the temperature on the compression strength parallel to grain of paricá. Constr Build Mater 24(1):99-104.

Navi, P.; Sandberg, D. 2012. Thermo-hydro-mechanical wood processing. CRC Press.

Percin, O.; Peker, H.; Atilgan, A. 2016. The effect of heat treatment on the some physical and mechanical properties of beech (Fagus orientalis L.) wood. Wood Research 61(3): 443-456.

Poncsak, S.; Kocaefe, D.; Bouazara, M.; Pichette, A. 2006. Effect of high temperature treatment on the mechanical properties of birch (Betula papyrifera). Wood Science and Technology 40(8): 647-663. 31.

Seborg, R.; Millet, M.; Stamm, A. 1945. Heat-stabilized compressed wood. Staypack. Mech Eng 67:25-

Seborg, R.; Tarkow, H.; Stamm, A. 1953. Effect of heat upon the dimensional stabilisation of wood. Forest Prod Journal 3(9):59-67. 
Shi, J.L.; Kocaefe, D.; Zhang, J. 2007. Mechanical behaviour of quebec wood species heat-treated using Thermo wood process. European Journal of Wood and Wood Products 65(4): 255-259.

Sulzberger, P.H. 1955. The effect of temperature on the strength of wood, plywood and glued joints (Doctoral dissertation, University of Tasmania), p:7.

Tiemann, H. 1920. Effect of different methods of drying on the strength and hygroscopicity of wood. $3^{\text {rd }}$ Ed. In: The kiln drying of lumber, J. P. Lippincott Co.

Turkish Standart Institute. TS. 1977. Wood-determination of ultimate stress in compression parallel to grain. TS 2595. 1977. TSE: Ankara.

Turkish Standart Institute. TS.1976. Wood-determination of ultimate strength in static bending. TS 2474. 1976. TSE: Ankara.

Turkish Standart Institute. TS. 1976. Wood-determination of modulus of elasticity in static bending. TS 2478. 1976. TSE: Ankara.

Turkish Standart Institute. TS. 1976. Wood-determination of impact bending strength. TS 2477. 1976. Turkish Standart Institute: Ankara Turkey.

Ulker, O.; Imirzi, O.; Burdurlu, E. 2012. The effect of densification temperature on some physical and mechanical properties of scots pine (Pinus sylvestris L.). Bioresources 7(4): 5581-5592.

Yapici, F.; Esen, R.; Yorur, H.; Likos, E. 2013. The effects of heat treatment on the modulus of rupture and modulus of elasticity of scots pine (Pinus Sylvestris L.) wood. NWSA-Technological Applied Sciences 2A0078 8(1): 1-6.

Zhong, Y.; Ren, H.Q.; Jiang, Z.H. 2016. Effects of temperature on the compressive strength parallel to the grain of bamboo scrimbe. Materials 9(6):436. 